\title{
Perspective
}

\section{Chandra Gayatri And Mind : Perspective from Indian Scriptures}

Neeti Tandon ${ }^{1 *}$

\author{
${ }^{1}$ Research Scholar, School of Studies in Physics, Vikram University, Ujjain, Madhya Pradesh, India \\ *Corresponding email: tandon.neeti2019@gmail.com \\ https://doi.org/10.36018/ijyr.v3i2.62
}

\begin{abstract}
Gayatri mantra is one of the most sacred chants to be found in Hindu lore, where an entire philosophy of Indian culture is compressed into these few syllables. Gayatri is the considered as supreme source with infinite divine forces. One of them is 'Chandra Gayatri'. Chandra (moon) has a strong relation in Indian Scripture. The aim of this perspective is to understand the importance of Chandra Gayatri Mantra in Vedic texts for reaching mental peace and stability.
\end{abstract}

Keywords. Chandra Gayatri, Mind, Mantra, Hawan, Indian Scripture

\section{Introduction}

Ancient Indian literature introduces the 'Gayatri' as the source of origin of universe (1). In the last phrase of Gayatri Mantra, 'dheyo yo naha prachodayat' (धियो यो नः प्रचोदयात) , person prays to almighty that the supreme energy guide them to virtuous path. All of the Indian Scriptures i.e. Ved, Upanishad, Brahman Aranyak, Ramayan, Mahabharat, Purana, describe the importance of Gayatri Mantra (2).

Scriptures describe there are infinite divine forces of Gayatri (2) and each one has its own Gayatri mantra. One of them is Chandra Gayatri Mantra for moon energy. Moon is the material symbol of divine energy of Chandra Gayatri (3). Through Chandra Gayatri Mantra spiritual practice and through its Hawan desired outcome is expected. In the present perspective, spiritual aspect of Chandra Gayatri mantra and hawan for mind has been explored.
Spiritual aspect of Chandra Gayatri mantra

"The Chandra (moon) is called Rasadhipati Overlord of Rasa. Chandra generates juice and flora on the earth. It is also the work of the Chandra to inspire Varuna for rain and for Parjanya. The origin of the child is also related to the lunar power. The child who has more of moon-element has more beautiful, gentle and calm in nature. Worship of the Chandra is beneficial in for food, animals, subjects, children, vegetation, trees, rain etc.” (4). Shrimad Bhagvad Geeta (Chapter 15 Sloka 13) describes 'Rasa' as supreme force nourishing the plants for medicinal benefits though moonelement (5).

Chandra is the one of the prime divine forces. Prana (Sun element) and Rayi (moon element) are two essential forces for life. 'Rasa' of Chandrama referred by Vedic texts is a very broad terminology. Rasa literally means Juice, but scripture applied it to all system. For example, Rasa brings beauty and peace in child, 
medicinal properties in plant, happiness of life, and so on. Rasa in the perspective of mind can be taken as interest, zeal, courage, etc (3).

As per the Indian scripture, moon element is strongly associated with mind. This association is reflected in the modern scientific studies too. Several modern scientific studies state that there is constant relationship between the moon cycle and mental health of the human (6). It has been reported that on the day of full moon maximum suicide has been attempt (7). Person feel mental restless during the full moon. The lunar cycle has an impact on human reproduction, in particular fertility, menstruation, and birth rate (8). These studies suggested there is clear relationship between moon element and mind. Indian scriptures described balancing of moon element for peaceful life. Chanting of Chandra Gayatri Mantra is prescribed in the Super Science of Gayatri for harmony, stability and power of mind.

The scriptures describes that the anger issues, nervous/ mental excitation, jealousy, poison accumulation in mind and body, can be treated by Chandra Gayatri mantra practice. For obtaining Inner peace and concentration, Chandra Gayatri is very beneficial (4).

The mantra for Chandra Gayatri mantra is as following "Om BhoorBhuvaha Swaha Ksheer Putraya Vidmahe Amrit Tatvaya Dheemah Tannaha Chandra Prachodayat” (ॐ भूभुर्वः स्वः क्षीर पुत्राय विद्महे, अमृत तत्वाय धीमहि, तन्नः चन्द्र: प्रचोदयात) (4).

\section{Yagya with Chandra Gayatri Mantra}

Yagya holds very important position in Indian scriptures and known for non-separable part of Dharmic-anushthan (spiritual practices). Yagya brings wealth and peace to individual person and society. Hawan performed with Chandra Gayatri mantra gives peace to mind and various benefits can be observed. The scripture described it as following (taken from reference 4), 1) doing hawan using rice can give benefit of mental peace (2) by doing hawan of indigenous cows milk in agni also gives peace, 3 ) the kings were instructed to do hawan of 1 crore ahuti for stable and peaceful mind, 4) for rain, it has been described to do hawan with Vet (Saponaria Officinalis) plant's flower or leaves along with kheer (an Indian sweet dish made by milk and rice). This would result in good rain ,5) if a place is facing issues of heavy rain the one should do yagya of 100 Ahuti in rain to solve the issue of heavy rain, 5) doing yagya using dry dung of bull-calf results in growth of plants and high yield in fields along with that it also strengthen the breeding in animals, 6) Chandra Gayatri Yagya using Anna (grains) will result in high yielding of grains in crop, and using cereals will results in high yielding of cereals in crop.

Vedic scriptures describe requirement specific spiritual practices for each of above purposes. However, the discussion and research on those are out of scope of this perspective study. Besides, these practices are carried in Indian scriptures through Guru-disciple tradition.

\section{Conclusion}

Indian scriptures depict chanting and hawan of Chandra Gayatri mantra for peace of mind, coordination in family and society, strengthen the body and natural resources, along collaboration with nature. Summarily, Chandra Gayatri practice is very important for mind as Chandra Gayatri mantra chanting can give stability to mind as well as can also help to get in synchronization with nature. 


\section{Reference}

1. Naicker S. An analysis of the Gayatri mantra as a mega-compression: A cognitive linguistic perspective in light of conceptual blending theory. HTS Teol Stud Theol Stud. $2019 \quad$ Nov 27;75. https://doi.org/10.4102/hts.v75i4.5325

2. Brahmavarchas (Editor). Gayatri Ki Asankhya Shaktiya in Gayatri Sadhana Kee Vaigyanik Prishthabhoomi, Pandit Shriam Sharma Acharya Vangmay 14. Second Edition, Akhand Jyoti Sansthan Publication, Mathura, 1998, Page 1.1

3. Pandya P. Discourse on Meditation on Moon (Chandrama ka Dhyan) at Dev Sanskriti Vishwavidyalaya 2004. Available from: Youtube Channel-'Shantikunjvideo' https://www.youtube.com/watch?v=umAfVbaGWhw

4. Brahmavarchas (Editor). "Udved Shanti ke Liye" in Yagya Ka Gyan-Vigyan (Hindi)", Pandit Shriram Sharma Acharya Samagra Vangamaya - Volume 25. Second Edition. Akhand Jyoti Sansthan, Mathura, Uttar Pradesh, India. 1988, Page 3.33
5. Shrimad Bhagwat Gita, Gita Press Gorakhpur. 2018.

6. Raison CL, Klein HM, Steckler M. The moon and madness reconsidered. J Affect Disord. 1999 Apr;53(1):99-106. h. htps://doi.org/10.1016/S01650327(99)00016-6

7. Biermann $\mathrm{T}$, Estel D, Sperling W, Bleich S, Kornhuber J, Reulbach U. Influence of lunar phases on suicide: the end of a myth? A population-based study. Chronobiol Int. 2005;22(6):1137-43. https://doi.org/10.1080/07420520500398114

8. Zimecki M. The lunar cycle: effects on human and animal behavior and physiology. PostepyHig Med Doswiadczalnej Online. 2006;60:1-7 